\title{
Een systematische kwalitatieve typering van arbeidsmarktinformatie
}

Citation for published version (APA):

Wieling, M., de Grip, A., \& Willems, E. J. T. A. (1990). Een systematische kwalitatieve typering van arbeidsmarktinformatie. Researchcentrum voor Onderwijs en Arbeidsmarkt, Faculteit der Economische Wetenschappen. ROA Working Papers No. 8 https://doi.org/10.26481/umarow.1990008

Document status and date:

Published: 01/01/1990

DOI:

10.26481/umarow.1990008

Document Version:

Publisher's PDF, also known as Version of record

\section{Please check the document version of this publication:}

- A submitted manuscript is the version of the article upon submission and before peer-review. There can be important differences between the submitted version and the official published version of record.

People interested in the research are advised to contact the author for the final version of the publication, or visit the DOI to the publisher's website.

- The final author version and the galley proof are versions of the publication after peer review.

- The final published version features the final layout of the paper including the volume, issue and page numbers.

Link to publication

\footnotetext{
General rights rights.

- You may freely distribute the URL identifying the publication in the public portal. please follow below link for the End User Agreement:

www.umlib.nl/taverne-license

Take down policy

If you believe that this document breaches copyright please contact us at:

repository@maastrichtuniversity.nl

providing details and we will investigate your claim.
}

Copyright and moral rights for the publications made accessible in the public portal are retained by the authors and/or other copyright owners and it is a condition of accessing publications that users recognise and abide by the legal requirements associated with these

- Users may download and print one copy of any publication from the public portal for the purpose of private study or research.

- You may not further distribute the material or use it for any profit-making activity or commercial gain

If the publication is distributed under the terms of Article $25 \mathrm{fa}$ of the Dutch Copyright Act, indicated by the "Taverne" license above, 


\section{EEN SYSTEMATISCHE KWALITATIEVE TYPERING VAN ARBEIDSMARKTINFORMATIE}

ROA-W-1990/8

M.H. Wieling, A. de Grip, E.J.T.A. Willems

\section{RESEARCHCENTRUM VOOR ONDERWIJS EN ARBEIDSMARKT}

Faculteit der Economische Wetenschappen

Rijksuniversiteit Limburg

Maastricht, december 1990 


\section{INHOUDSOPGAVE}

VERANTWOORDING

1. INLEIDING

2. METHODE VOOR EEN SYSTEMATISCHE GRENZENINDELING

3. HISTORISCHE DATA, RISICO-INDICATOREN EN TRENDS 7

3.1. Historische data 7

3.2. Risico-indicatoren 11

3.3. Trends 14

4. ARBEIDSMARKTPROGNOSES 18

4.1. Prognoses beroepsklassen en opleidingstypen 18

4.2. Indicator van de toekomstige arbeidsmarktsituatie 21

5. BESLUIT 24

$\begin{array}{lr}\text { LITERATUUR } & 26\end{array}$

$\begin{array}{lr}\text { BIJLAGE A: LIJST MET AFKORTINGEN } & 27\end{array}$

BIJLAGE B: GEMIDDELDEN EN STANDAARDDEVIATIES VAN DE VARIABELEN 28 


\section{VERANTWOORDING}

Deze studie is uitgevoerd in het kader van de ontwikkeling van het informatiesysteem onderwijs-arbeidsmarkt van het Researchcentrum voor Onderwijs en Arbeidsmarkt (ROA), dat onder meer bruikbaar is voor de studie- en beroepskeuzevoorlichting aan leerlingen in het voortgezet en hoger onderwijs.

In het informatiesysteem voor beroeps- en studiekeuze I-See! worden aan de gepresenteerde kwantitatieve arbeidsmarktinformatie (historische data, risico-indicatoren en arbeidsmarktprognoses), kwalificaties toegekend. In dit werkdocument wordt verslag gedaan van de wijze waarop deze kwalitatieve typeringen zijn onderbouwd. Er is getracht te komen tot een systematische methode om de in het ROA-informatiesysteem gepresenteerde gegevens in te delen.

Het onderzoek werd, onder begeleiding van dr. A. de Grip, uitgevoerd door drs. M.H. Wieling met medewerking van drs. E.J.T.A. Willems. 


\section{INLEIDING}

Het Researchcentrum voor Onderwijs en Arbeidsmarkt (ROA) verzorgt in het kader van het informatiesysteem voor beroeps- en opleidingskeuze I-See! de informatie waarmee de arbeidsmarktmodule is gevuld (zie Dekker, De Grip, Beekman, Van de Loo, Wieling en Willems, 1990). Het ROA verstrekt arbeidsmarktinformatie voor beroepsklassen en opleidingstypen. Voor zowel de beroepen- als de onderwijscomponent van de arbeidsmarktmodule zijn feitelijke ('historische') data aangeleverd en risico-indicatoren en prognoses opgesteld. Daarnaast is voor vrijwel alle historische data en indicatoren de trendmatige ontwikkeling bepaald.

In de meeste gevallen wordt de kwantitatieve informatie vertaald naar kwalitatieve typeringen. De reden hiervoor is dat de gebruiker van I-See! de waarde van de variabelen waarschijnlijk vaak moeilijk zal kunnen interpreteren of mogelijk teveel waarde ontleent aan relatief kleine verschillen. Dit laatste geval doet zich vooral voor bij de interpretatie van de prognoseuitkomsten. Door aan de op het beeldscherm gepresenteerde gegevens een kwalitatieve typering toe te kennen, wordt de interpretatie van de gegevens vereenvoudigd. De beoogde signaalwerking naar de doelgroep zal hierdoor worden vergroot. Bij de gepresenteerde kwalitatieve typeringen is in de meeste gevallen gekozen voor een typering in vijf categorieën te weten:

- relatief erg hoog/erg groot;

- relatief hoog/groot;

- gemiddeld;

- relatief laag/klein;

- relatief erg laag/erg klein.

Daarnaast wordt voor de ontwikkelingstrends telkens de volgende indeling gehanteerd:

- sterk dalend;

- dalend;

- constant;

- stijgend;

- sterk stijgend.

In dit werkdocument wordt verslag gedaan van de wijze waarop is getracht tot een systematische methode te komen om kwalificaties toe te kennen aan de vanuit het ROAinformatiesysteem onderwijs-arbeidsmarkt te presenteren informatie ten behoeve van de beroeps- en opleidingskeuze. Dit heeft geresulteerd in een drietal verschillende methoden. Afhankelijk van de aard van de te presenteren informatie is een van deze methoden toegepast. 
Voor de 80 onderscheiden beroepsklassen, 303 beroepsgroepen en 54 opleidingstypen zijn voor de volgende historische data kwalitatieve typeringen bepaald:

- werkloosheidspercentage per opleidingstype;

- percentage werkenden per opleidingstype en aandeel in de totale werkgelegenheid;

- percentage werkenden per beroepsklasse en aandeel in de totale werkgelegenheid;

- gemiddelde leeftijd per beroepsklasse;

- gemiddeld aantal jaren opleiding per beroepsklasse;

- percentage zelfstandigen per beroepsklasse;

- gemiddeld aantal werkenden per beroepsgroep;

- percentage vrouwen per beroepsgroep;

- percentage deeltijdwerkers per beroepsgroep.

Tevens wordt voor de beroepsklassen en opleidingstypen een drietal risico-indicatoren getypeerd:

- conjunctuurgevoeligheid;

- branchespreiding van de werkgelegenheid per beroepsklasse;

- branche- en beroepenspreiding per opleidingstype.

Voor vrijwel alle historische data en indicatoren wordt in het informatiesysteem tevens de trendmatige ontwikkeling in de tijd gepresenteerd. Hierbij moet worden opgemerkt dat de classificering van de trendmatige ontwikkeling van de werkloosheid afwijkt van de overige trends, omdat de eerstgenoemde trend betrekking heeft op de kortere periode 1987-1990, terwijl de trendmatige ontwikkeling van de andere historische data en risico-indicatoren is bepaald op basis van de ontwikkeling in de jaren 1979-1985.

Voor de beroepsklassen en opleidingstypen wordt bovendien een kwalitatieve typering gegeven van de volgende middellange-termijn prognoses:

- uitbreidingsvraag per beroepsklasse en opleidingstype;

- vervangingsvraag per beroepsklasse en opleidingstype;

- totale vraag per beroepsklasse en opleidingstype;

- toekomstige instroom van schoolverlaters op de arbeidsmarkt.

Tenslotte wordt op basis van de indicator van de toekomstige arbeidsmarktsituatie voor alle opleidingstypen de verwachte toekomstige arbeidsmarktpositie voor afgestudeerden/schoolverlaters getypeerd. 
$-3-$

De verdere opzet van dit werkdocument is als volgt. Eerst wordt in hoofdstuk 2 een drietal methoden voor een systematische grenzenindeling besproken. Vervolgens worden in hoofdstuk 3 de resulterende indelingen voor de historische data, de risico-indicatoren en de trends weergegeven. Hoofdstuk 4 behandelt de grenzenindelingen van de arbeidsmarktprognoses. Voor alle in hoofdstuk 3 en 4 genoemde variabelen zal worden aangegeven hoe de verdeling is van de beroepsklassen, beroepsgroepen en opleidingstypen over de onderscheiden typeringen.

Op de wijze waarop de onderliggende kwantitatieve arbeidsmarktinformatie is berekend zal in deze studie niet worden ingegaan, tenzij dit relevant is voor de bepaling van de grenzen. Dit laatste is alleen het geval bij de indicator van de toekomstige arbeidsmarktsituatie. In hoofdstuk 5 worden nog enkele evaluerende opmerkingen gemaakt. Tenslotte wordt verwezen naar bijlage $A$ en B. Bijlage A geeft een overzicht van de in dit werkdocument gebruikte symbolen. In bijlage $B$ worden de voor de diverse variabelen berekende gemiddelden en standaardafwijkingen gepresenteerd. 


\section{METHODE VOOR EEN SYSTEMATISCHE GRENZENINDELING}

Bij het vaststellen van de typeringen voor de in het informatiesysteem te presenteren historische data, risico-indicatoren en arbeidsmarktvoorspellingen moeten een aantal keuzen worden gemaakt. Een eerste afweging betreft de keuze tussen een al dan niet relatieve grenzenindeling. Bij een relatieve indeling geldt dat de classificatie van de variabele voor een bepaalde beroepsklasse of een bepaald opleidingstype afhankelijk wordt gemaakt van de waarden van de desbetreffende variabele bij de andere beroepsklassen of opleidingstypen. Het gevolg hiervan is dat de grenzenindeling verandert bij elke wijziging van de gegevens. Wanneer daarentegen een niet-relatieve grenzenindeling wordt gehanteerd, wordt per beroepsklasse of opleidingstype een kwalitatieve uitspraak over een variabele gedaan, zonder daarbij rekening te houden met de waarde van deze variabele bij de andere beroepsklassen of opleidingstypen. Aangezien de gebruiker van I-See!, voorzover deze voor een bepaalde keuze staat, in veel gevallen waarschijnlijk vooral geïnteresseerd zal zijn in de verschillen tussen de diverse beroepsklassen en opleidingstypen, ligt een relatieve indeling het meest voor de hand.

Indien wordt uitgegaan van een relatieve grenzenindeling kunnen enkele verschillende wijzen van aanpak worden onderscheiden. Op drie van deze mogelijkheden wordt in deze studie verder ingegaan:

- de symmetrische methode;

- de kwantielenmethode;

- de ad hoc methode.

Bij de symmetrische methode wordt de grenzenindeling zodanig vastgesteld dat de verschillende beroepsklassen of opleidingstypen symmetrisch worden verdeeld over de vijf onderscheiden typeringen. Daarbij wordt gebruik gemaakt van het gemiddelde $(\mu)$ en de standaardafwijking $(\sigma)$ van de te kwalificeren gegevens. Met behulp van de verdelingsfunctie van de normale verdeling kan vervolgens een symmetrische grenzenindeling worden verkregen. De variabele $x$ kan dan als volgt worden getypeerd:

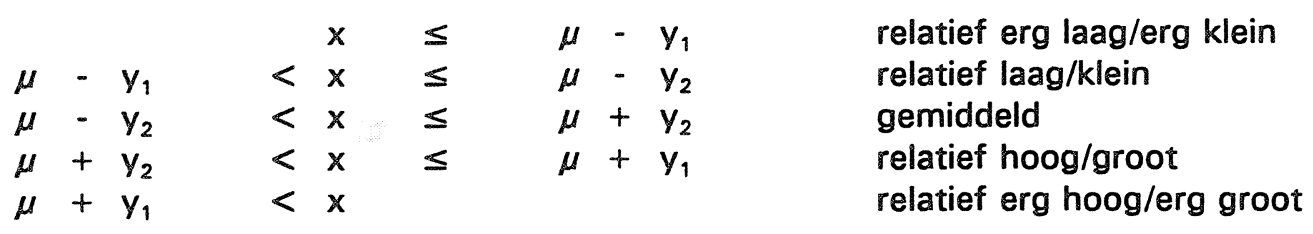

Daarbij worden de waarden van $y_{1}$ en $y_{2}$ zodanig gekozen dat de typering van $x$ als volgt over de berekende waarden van variabele $\mathrm{x}$ is verdeeld: 
- 20\% van de beroepsklassen of opleidingstypen krijgt de typering 'relatief erg hoog/erg groot' en 'relatief erg laag/erg klein';

- $40 \%$ van de beroepsklassen of opleidingstypen wordt getypeerd als 'relatief hoog/groot' en 'relatief groot/laag';

- $40 \%$ van de beroepsklassen of opleidingstypen krijgt de typering 'gemiddeld'.

Dan geldt:

$$
P\left\{x \leq \mu-y_{1}\right\}=0,10
$$

en

$$
P\left\{x \leq \mu-y_{2}\right\}=0,30
$$

zodat:

$$
y_{1}=1,282 \sigma
$$

en

$y_{2}=0,524 \sigma$

De symmetrische grenzenindeling wordt derhalve:

$$
\begin{array}{r}
x-1,282 \sigma<\mathrm{x} \leq \mu-1,282 \sigma \\
\mu-1,524 \sigma \\
\mu-0,524 \sigma<\mathrm{x} \leq \mu+0,524 \sigma \\
\mu+0,524 \sigma<\mathrm{x} \leq \mu+1,282 \sigma \\
\mu+1,282 \sigma<\mathrm{x} \leq
\end{array}
$$

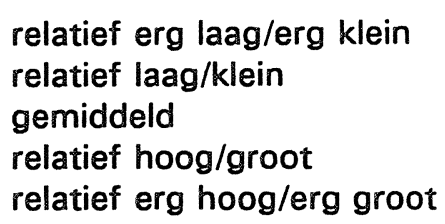

Voor alle in I-See! gepresenteerde variabelen zijn het gemiddelde en de standaarddeviatie berekend. Deze uitkomsten zullen niet in de tekst worden vermeld. Hiervoor wordt verwezen naar bijlage $B$.

De kwantielenmethode gaat uit van een niet noodzakelijkerwijs symmetrische grenzenindeling. De berekende waarden van de te typeren variabele worden als volgt in vijf klassen ingedeeld:

- $10 \%$ van de beroepsklassen of opleidingstypen krijgt de typering 'relatief erg hoog/erg groot';

- $20 \%$ van de beroepsklassen of opleidingstypen krijgt de typering 'relatief hoog/groot';

- $40 \%$ van de beroepsklassen of opleidingstypen krijgt de typering 'gemiddeld';

- $20 \%$ van de beroepsklassen of opleidingstypen krijgt de typering 'relatief laag/klein';

$-10 \%$ van de beroepsklassen of opleidingstypen krijgt de typering 'relatief erg laag/erg klein'.

De kwantielenmethode wijkt op een tweetal punten af van de symmetrische methode. In de eerste plaats gaat de symmetrische methode uit van het gemiddelde van de waarden van de te typeren variabele, terwijl dit bij de kwantielenmethode niet het geval is. Bovendien geldt dat bij de kwantielenmethode het aantal beroepsklassen, beroepsgroepen of opleidingstypen behorende 
tot een bepaalde kwalitatieve typering vooraf vastligt. Bij de symmetrische methode ligt daarentegen slechts het aantal beroepsklassen, beroepsgroepen of opleidingstypen in de combinatie van een tweetal categorieën (bijvoorbeeld 'relatief erg hoog/erg groot' samen met 'relatief erg laag/erg klein') van te voren vast.

Als er sprake is van een sterk 'scheve' verdeling van een bepaalde variabele zijn de beide hierboven beschreven methoden minder geschikt als basis voor de indelingen. In dat geval zal moeten worden overgegaan op een min of meer ad hoc indeling van de waarden van de betreffende variabele. Bij de ad hoc methode is een evenwichtige spreiding van de beroepsklassen, beroepsgroepen of opleidingstypen over de kwalitatieve typeringen telkens als uitgangspunt gekozen.

Bij het typeren van de waarden die de onderscheiden variabelen aannemen is iedere keer in eerste instantie uitgegaan van de symmetrische grenzenindeling. Een voordeel van de symmetrische methode, naast de symmetrie van de grenzen rondom het gemiddelde, is de gelijke klassenbreedte van de categorieën 'relatief laag/klein' en 'relatief hoog/groot'. Bij de kwantielenmethode daarentegen kunnen de klassenbreedten verschillen. Zoals in hoofdstuk 3 en 4 zal blijken, is in een aantal gevallen de spreiding van de variabele echter dermate groot dat het bepalen van de grenzen met behulp van de symmetrische methode weinig zinvol is. In deze gevallen is geprobeerd aan de hand van de kwantielenmethode de gerealiseerde en voorspelde waarden van de variabelen te typeren. In enkele gevallen is de verdeling van een van de te typeren variabelen echter extreem scheef. Dit heeft tot gevolg dat de grenzen bij de kwantielenmethode zeer dicht bij elkaar komen te liggen of zelfs aan elkaar gelijk zijn. Voor deze variabelen is een ad hoc indeling toegepast, waarbij zoveel mogelijk is getracht te komen tot een evenwichtige opvulling van de vijf onderscheiden typeringen. 


\section{HISTORISCHE DATA, RISICO-INDICATOREN EN TRENDS}

\subsection{Historische data}

In deze paragraaf worden de grenzenindelingen voor de feitelijke (historische) data besproken. Als eerste komt de typering van het per opleidingstype bepaalde werkloosheidspercentage aan de orde. Daarna worden de classificaties voor het aantal werkenden in de onderscheiden beroepsklassen of opleidingstypen uitgedrukt in procenten van het totaal aantal werkenden, weergegeven. Vervolgens zijn voor de gemiddelde leeftijd, het gemiddeld aantal jaren opleiding en het percentage zelfstandigen per beroepsklasse de bijbehorende kwalitatieve typeringen vastgesteld. Tenslotte worden de indelingen gepresenteerd die betrekking hebben op een drietal variabelen die per beroepsgroep zijn bepaald, namelijk het gemiddeld aantal werkenden, het percentage vrouwen en het percentage deeltijdwerkers.

Het werkloosheidspercentage per opleidingstype (W) is een maatstaf voor de actuele arbeidsmarktsituatie van het desbetreffende opleidingstype. De verdeling van de werkloosheidspercentages per opleidingstype is scheef naar de lage percentages. Het heeft daarom weinig zin om de klassenindeling van het werkloosheidspercentage per opleidingstype te bepalen aan de hand van de symmetrische methode. Ook de kwantielenindeling brengt in dit geval geen oplossing, omdat de grenzen aan de zijde van de lage werkloosheidspercentages erg dicht bij elkaar komen te liggen. Daarom is gekozen voor een op ad hoc wijze bepaalde indeling. Bij deze ad hoc benadering is uitgegaan van het werkloosheidspercentage van de totale beroepsbevolking (10\%). Dit heeft geleid tot de onderstaande indeling:

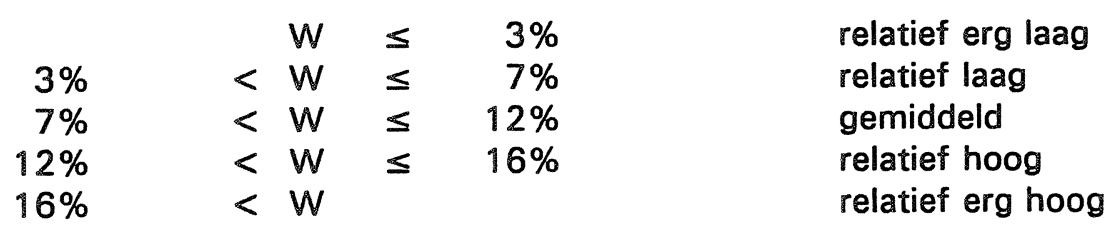

De volgende twee variabelen, het percentage werkenden per beroepsklasse (BW) en het percentage werkenden per opleidingstype (OW), zijn bedoeld om de relatieve omvang van een bepaald arbeidsmarktsegment aan de te geven. Het aantal werkenden in desbetreffende beroepsklasse of met desbetreffende opleidingsachtergrond wordt daarbij uitgedrukt in procenten van het totaal aantal werkenden. Voor beide variabelen geldt dat de standaarddeviatie relatief groot is. Zoals in hoofdstuk 2 werd aangegeven is het derhalve weinig zinvol om met behulp van de symmetrische methode de grenzen voor deze variabelen te bepalen. De indeling van beide variabelen is daarom vastgesteld aan de hand van de kwantielen- 
-8-

indeling met kwantielen van respectievelijk 10\%-20\%-40\%-20\%-10\%. Dit levert voor het percentage werkenden per opleidingstype de volgende indeling op:

$\begin{array}{llll} & \text { OW } \leq & 0,05 \% & \text { relatief erg laag } \\ 0,05 \% & <\text { OW } \leq & 0,25 \% & \text { relatief laag } \\ 0,25 \% & <\text { OW } \leq & 1,00 \% & \text { gemiddeld } \\ 1,00 \% & <\text { OW } \leq & 4,50 \% & \begin{array}{l}\text { relatief hoog } \\ \text { relatief erg hoog }\end{array} \\ 4,50 \% & <\text { OW } & & \end{array}$

Dezelfde methode levert voor het percentage werkenden per beroepsklasse onderstaande grenzen op:

$\begin{array}{llll}0,10 \% & \text { BW } \leq & 0,10 \% & \text { relatief erg laag } \\ 0,25 \% & <\text { BW } \leq & 0,25 \% & \text { relatief laag } \\ 0,00 \% & \text { gemiddeld } \\ 1,00 \% & <\text { BW } \leq & 3,50 \% & \begin{array}{l}\text { relatief hoog } \\ \text { relatief erg hoog }\end{array} \\ 3,50 \% & <\text { BW } & & \end{array}$

De gemiddelde leeftijd per beroepsklasse (L) vormt een globale maatstaf voor de mate waarin een bepaalde beroepsklasse een 'starters'- of 'eindberoep' is. Bij de typering van de gemiddelde leeftijd per beroepsklasse is op basis van de symmetrische methode de volgende grenzenindeling (in jaren) bepaald:

\begin{tabular}{|c|c|c|c|c|}
\hline & L & $\leq$ & 33 jaar & relatief erg laag \\
\hline 33 jaar & $<$ & $\leq$ & 35 jaar & relatief laag \\
\hline 35 jaar & $<$ & $\leq$ & 39 jaar & gemiddeld \\
\hline 39 jaar & $<$ & $\leq$ & 41 jaar & relatief hoog \\
\hline 41 jaar & $<L$ & $\leq$ & 65 jaar & relatief erg hoog \\
\hline
\end{tabular}

Aangezien door de erg dicht bij elkaar liggende grenzen het onderscheid tussen respectievelijk 'relatief erg hoog' en 'relatief hoog' en 'relatief erg laag' en 'relatief laag' niet gerechtvaardigd lijkt, is besloten deze typeringen hier samen te voegen. Er ontstaat dan een indeling in drie categorieën:

$\begin{array}{lllll}35 \text { jaar } & L & L & 35 \text { jaar } & \\ 39 \text { jaar } & <L & 39 \text { jaar } & \text { relatief laag } \\ & & 65 \text { jaar } & \text { gemiddeld } \\ \text { relatief hoog }\end{array}$

Om een indicatie van de opleidingstructuur van de werkgelegenheid te krijgen, kan worden nagegaan wat het gemiddelde opleidingsniveau van de werkenden in de afzonderlijke beroepsklassen is. Het gemiddelde opleidingsniveau is berekend door aan gediplomeerde schoolverlaters van de verschillende schoolsoorten een bepaald aantal opleidingsjaren toe te 
$-9-$

kennen (zie De Grip, 1987). Voor het gemiddeld aantal jaren opleiding per beroepsklasse (VO) is met behulp van de symmetrische methode de grenzenindeling bepaald. De indeling luidt als volgt:

$\begin{aligned} 7 \text { jaar } & <\mathrm{VO} \leq 7 \text { jaar } \\ 9 \text { jaar } & <\mathrm{VO} \leq 12 \text { jaar } \\ 12 \text { jaar } & <\mathrm{VO} \leq 14 \text { jaar } \\ 14 \text { jaar } & <\mathrm{VO}\end{aligned}$

relatief erg laag

relatief laag

gemiddeld

relatief hoog

relatief erg hoog

Het percentage zelfstandigen per beroepsklasse (Z) geeft een indicatie van de mate waarin het mogelijk is zich in een bepaald beroep als zelfstandige te vestigen. Een indeling op basis van de symmetrische of de kwantielenmethode heeft voor het percentage zelfstandigen per beroepsklasse geen zin. De zelfstandig werkenden zijn namelijk slechts in een aantal beroepsklassen geconcentreerd, terwijl voor een groot aantal beroepsklassen het percentage zelfstandigen (vrijwel) gelijk is aan 0 . Derhalve is voor deze variabele een ad hoc indeling gehanteerd:

$\begin{array}{rllll} & Z & = & 0 \% & \\ 0 \% & <Z & \leq & 10 \% & \begin{array}{l}\text { relatief erg laag } \\ \text { relatief laag }\end{array} \\ 10 \% & <Z & \leq & 20 \% & \text { gemiddeld } \\ 20 \% & <Z & \leq & 50 \% & \begin{array}{l}\text { relatief hoog } \\ \text { relatief erg hoog }\end{array} \\ 50 \% & <Z & & & \end{array}$

De grens voor de afbakening tussen 'relatief hoog' en 'relatief erg hoog' is hierbij op $50 \%$ gelegd. In de praktijk betekent dit echter dat de laatstgenoemde groep bestaat uit beroepsklassen waarin vrijwel alleen zelfstandigen werkzaam zijn.

Naast de historische data per beroepsklasse en opleidingstype, worden in I-See! ook een aantal gegevens verstrekt op het meer gedesaggrereerde niveau van beroepsgroepen. Per beroepsgroep wordt het aantal werkenden (BGR), het percentage vrouwen (V) en het percentage deeltijdwerkers (D) gepresenteerd. Hiermee wordt informatie gegeven over respectievelijk de relatieve omvang van een bepaald meer specifiek arbeidsmarktsegment, de mate waarin vrouwen worden gerecruteerd en de mate waarin in de desbetreffende beroepsgroep in deeltijd kan worden gewerkt.

De standaarddeviaties van deze drie variabelen zijn ten opzichte van de bijbehorende gemiddelden relatief groot. Er is sprake van een scheve verdeling van deze variabelen. Dit maakt het bepalen van de grenzen met behulp van de symmetrische methode en de 
$-10-$

kwantielenmethode niet erg zinvol. Voor de betreffende variabelen is derhalve de grenzenindeling op ad hoc basis bepaald:

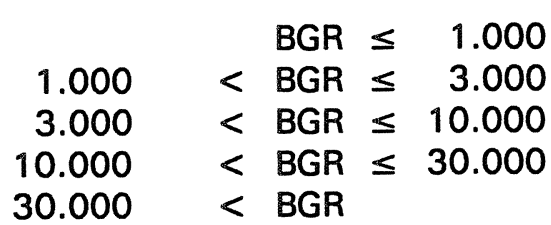

$\begin{array}{rlll} & V & \leq & 2 \% \\ 2 \% & <V & \leq & 10 \% \\ 10 \% & <V & \leq & 25 \% \\ 25 \% & <V & \leq & 50 \% \\ 50 \% & <V & & \end{array}$

$\begin{array}{rrrr} & D & \leq & 2 \% \\ 2 \% & <D & \leq & 10 \% \\ 10 \% & <D & \leq & 25 \% \\ 25 \% & < & \leq & 50 \% \\ 50 \% & < & \end{array}$

\author{
relatief erg laag \\ relatief laag \\ gemiddeld \\ relatief hoog \\ relatief erg hoog
}

relatief erg laag

relatief laag

gemiddeld

relatief hoog

relatief erg hoog

relatief erg laag

relatief laag

gemiddeld

relatief hoog

relatief erg hoog

Voor het percentage vrouwen en het percentage deeltijdwerkers per beroepsgroep is derhalve dezelfde indeling gehanteerd. Dit ligt enigszins voor de hand, daar een groot deel van de deeltijdwerkers uit vrouwen bestaat.

Verdeling van de typeringen

Tabel 1 geeft een beeld van de wijze waarop de typeringen van de hierboven behandelde historische data zijn verdeeld over de onderscheiden beroepsklassen, beroepsgroepen en opleidingstypen.

Tabel 1. Verdeling van de typeringen van de verschillende historische data over de beroepsklassen, beroepsgroepen en opleidingstypen

\begin{tabular}{lrrrrrrrrr}
\hline typering & W & OW & BW & L & VO & Z & BGR & V & D \\
\hline relatief erg laag & 20 & 7 & 9 & - & 6 & 29 & 43 & 106 & 102 \\
relatief laag & 15 & 11 & 11 & 30 & 29 & 30 & 71 & 67 & 109 \\
gemiddeld & 7 & 19 & 35 & 32 & 29 & 10 & 71 & 55 & 52 \\
relatief hoog & 7 & 11 & 18 & 18 & 10 & 7 & 77 & 38 & 30 \\
relatief erg hoog & 5 & 6 & 7 & - & 6 & 4 & 41 & 37 & 10 \\
totaal & 54 & 54 & 80 & 80 & 80 & 80 & 303 & 303 & 303 \\
\hline
\end{tabular}


In tabel 1 kan de kwantielenmethode, die is toegepast bij het percentage werkenden per beroepsklasse (BW) en opleidingstype (OW), duidelijk worden herkend'. Voor het percentage vrouwen (V) en het percentage deeltijdwerkers (D) geldt dat veel beroepsgroepen tot de categorie 'relatief erg laag' en 'relatief laag' behoren. Het aantal beroepen waarin vrijwel geen vrouwen of deeltijdwerkers aanwezig zijn, is immers groot. In geringere mate geldt hetzelfde voor het percentage zelfstandigen per beroepsklasse $(Z)$. Daarentegen zijn de verdelingen voor de gemiddelde leeftijd (L) en het aantal jaren opleiding (VO) gelijkmatiger verdeeld over de onderscheiden typeringen, waarbij wel opvalt dat het aantal beroepsklassen dat in de categorie 'relatief erg laag' valt groot is. De werkloosheidspercentages (W) tenslotte, zijn relatief vaak toebedeeld aan de categorieën 'relatief laag' en 'relatief erg laag', hetgeen een beeld geeft van de scheefheid van de verdeling van de werkloosheid naar opleidingstype.

\subsection{Risico-indicatoren}

De risico-indicatoren die in het kader van I-See! zijn bepaald, zijn de indicator voor de conjunctuurgevoeligheid, de branchespreiding van de werkgelegenheid per beroepsklasse en de branchespreiding en de beroepenspreiding per opleidingstype. De grenzenindelingen van deze indicatoren zullen hieronder achtereenvolgens worden besproken.

Om de conjunctuurgevoeligheid, ofwel de mate van werkzekerheid, in de afzonderlijke bedrijfssectoren te traceren, kan worden nagegaan hoe de reactie van de werkgelegenheid op conjunctuurschommelingen in het verleden is geweest. Hiertoe is een fluctuatie-index geconstrueerd. Deze index wordt uitgedrukt als het quotiënt van de afwijking van de trendmatige werkgelegenheidsontwikkeling van een bepaalde bedrijfssector in een bepaald jaar en de trendmatige werkgelegenheidsontwikkeling van de desbetreffende bedrijfssector. Vervolgens wordt de index voor elke beroepsklasse bepaald door de indices van de sectoren te wegen met de aandelen van de sectoren in de totale werkgelegenheid van de desbetreffende beroepsklasse (zie De Grip en Heijke, 1988 en De Grip, Heijke en Dekker, 1989).

Bij de bepaling van de grenzen van de conjunctuurindicator $(\mathrm{Cl})$ is gebruik gemaakt van de symmetrische methode. De grenzenindeling van deze indicator ziet er als volgt uit²:

1. In de praktijk wijkt de verdeling van de typeringen van de beide variabelen enigszins af van de theoretische verdeling van de kwantielenmethode. Dit is het gevolg van het afronden van de grenzen.

2. Deze indeling wijkt, als gevolg van een andere afronding van de getallen, iets af van de indeling zoals die in I-See! 1990 is gehanteerd. 
$-12-$

$\begin{array}{llll} & \mathrm{Cl} \leq & 1,00 & \text { relatief erg klein } \\ 1,00 & \mathrm{Cl} \leq & 1,45 & \text { relatief klein } \\ 1,45<\mathrm{Cl} \leq & 2,05 & \text { gemiddeld } \\ 2,05<\mathrm{Cl} \leq & 2,50 & \text { relatief groot } \\ 2,50<\mathrm{Cl} & & & \text { relatief erg groot }\end{array}$

Een indicatie van de bestaande flexibiliteit op de arbeidsmarkt wordt gegeven door de GiniHirschman coëfficiënt (zie Sheldon, 1985, Warnken, 1986 en De Grip en Heijke, 1988). Men kan hier ook spreken van de uitwijkmogelijkheden op de arbeidsmarkt. Op basis van deze maatstaf wordt een typering gegeven van de branchespreiding per beroepsklasse en de branchespreiding en de beroepenspreiding van de verschillende opleidingstypen. De branchespreiding per beroepsklasse geeft een indruk van de uitwijkmogelijkheden die beroepsbeoefenaren hebben naar andere bedrijfssectoren, met behulp van de verdeling van de werkgelegenheid in de betreffende beroepsklasse over de verschillende bedrijfssectoren. Zo kan ook voor de opleidingen de spreiding van de werkenden met een bepaalde opleidingsachtergrond over de beroepsklassen en bedrijfssectoren worden vastgesteld. Een groot voordeel van de Gini-Hirschman spreidingsindicator is de zeer gemakkelijke interpretatie ervan. De indicator kan slechts waarden aannemen tussen 0 en 1. De branche- of beroepenspreiding van opleidingen is 0 als het opleidingstype slechts in én branche of beroep voorkomt en 1 als het opleidingstype gelijkmatig over alle branches of beroepen is verspreid. Hetzelfde geldt voor de branchespreiding van de beroepen.

De classificatie voor de branchespreiding van de werkgelegenheid per beroepsklasse (BS), die op basis van de symmetrische methode is bepaald, komt er als volgt uit te zien:

$\begin{array}{llll}0,10 & \text { BS } \leq & 0,10 & \text { relatief erg klein } \\ 0,35 & \leq & 0,35 & \text { relatief klein } \\ 0,35 & <\text { BS } \leq & 0,65 & \text { gemiddeld } \\ 0,65 & <\text { BS } \leq & 0,90 & \text { relatief groot } \\ 0,90<\text { BS } & 1,00 & \text { relatief erg groot }\end{array}$

De tweede spreidingsindicator die in het kader van I-See! is bepaald, is de branchespreiding van opleidingstypen (OS). Voor de branchespreiding van opleidingstypen geldt dat de typering 'erg groot' zou vervallen indien de indeling wordt bepaald met behulp van de symmetrische methode. De betreffende grens komt boven de waarde 1 te liggen, terwijl de spreidingsindicator, zoals gezegd, slechts waarden kan aannemen tussen 0 en 1 . Derhalve zijn de grenzen, zoals ze zouden voortvloeien uit de symmetrische methode, enigszins bijgesteld. 
$-13-$

$\begin{array}{llll} & O S \leq & 0,40 & \text { relatief erg klein } \\ 0,40<O S \leq & 0,60 & \text { relatief klein } \\ 0,60<O S \leq & 0,80 & \text { gemiddeld } \\ 0,80<O S \leq & 0,95 & \text { relatief groot } \\ 0,95<O S \leq 1,00 & \text { relatief erg groot }\end{array}$

De laatste spreidingsindicator die is bepaald, is de beroepenspreiding van de opleidingstypen (OB). Voor de beroepenspreiding van opleidingstypen geldt hetzelfde als bij de branchespreiding van de opleidingstypen: de typering 'erg groot' zou vervallen indien de indeling wordt bepaald met behulp van de symmetrische methode. Daarom moeten analoog aan de typering van de branchespreiding van opleidingstypen de grenzen, zoals ze zijn bepaald op basis van de symmetrische methode, enigszins worden bijgesteld. Dit leidt tot de onderstaande grenzen:

$\begin{array}{llll} & \mathrm{OB} \leq & 0,45 & \text { relatief erg klein } \\ 0,45 & <\mathrm{OB} \leq & 0,65 & \text { relatief klein } \\ 0,65 & <\mathrm{OB} \leq & 0,85 & \text { gemiddeld } \\ 0,85 & <\mathrm{OB} \leq & 0,95 & \text { relatief groot } \\ 0,95 & <\mathrm{OB} \leq & 1,00 & \text { relatief erg groot }\end{array}$

Verdeling van de typeringen

Tabel 2 geeft een beeld van de verdeling van de in deze paragraaf gepresenteerde indicatoren over de beroepsklassen of opleidingstypen.

Tabel 2. Verdeling van de typeringen van de verschillende indicatoren over de beroepsklassen en opleidingstypen

\begin{tabular}{lrrrr}
\hline & Cl & BS & OS & OB \\
typering & 1 & 12 & 10 & 8 \\
\hline relatief erg klein & 27 & 15 & 7 & 7 \\
relatief klein & 33 & 22 & 17 & 23 \\
gemiddeld & 9 & 10 & 1 & 15 \\
relatief groot & 10 & 80 & 54 & 1 \\
relatief erg groot & 80 & & 54 \\
totaal & & & & \\
\hline
\end{tabular}

Bij de conjunctuurindicator $(\mathrm{Cl})$ zien we dat er in een kwart van de beroepsklassen sprake is van een relatief grote of erg grote conjunctuurgevoeligheid. Wat betreft de spreidingsindicatoren kan worden opgemerkt dat de categorieën 'gemiddeld' en 'relatief groot' het meest voorkomen. 


\subsection{Trends}

Voor vrijwel alle historische data en indicatoren wordt in het informatiesysteem tevens de trendmatige ontwikkeling in de tijd gepresenteerd. Deze trends (T) geven een indicatie van de richting van de ontwikkelingen in het recente verleden. Deze trends zijn genormeerd ten opzichte van de waarde 1 , omdat er bij een waarde van 1 sprake is van een stabiele situatie. Aangezien voor vrijwel alle variabelen trends worden bepaald, is de typering hier niet relatief op de gegevens gemaakt, maar is voor een ad hoc benadering gekozen die in principe voor alle trendmatige ontwikkelingen kan worden gebruikt. Voor alle trends die in het kader van I-See! zijn bepaald, met uitzondering van de trendmatige ontwikkeling van de werkloosheid, is dan ook dezelfde grenzenindeling gehanteerd. Op deze wijze kan er een absolute uitspraak worden gedaan over de betreffende trend en indien dit relevant is kunnen de trends onderling worden vergeleken ${ }^{3}$. De indeling luidt als volgt:

\begin{tabular}{|c|c|c|c|c|}
\hline & $\mathrm{T}$ & $\leq$ & 0,80 & sterk dalend \\
\hline 0,80 & $<T$ & $\leq$ & 0,95 & dalend \\
\hline 0,95 & $<T$ & $\leq$ & 1,05 & constant \\
\hline 1,05 & $<$ & $\leq$ & 1,20 & stijgend \\
\hline 20 & $<\mathrm{T}$ & & & sterk stijgend \\
\hline
\end{tabular}

Zoals in de inleiding al is opgemerkt wijkt de classificering van de trend van de werkloosheid af van de indeling voor de overige trends, omdat de eerstgenoemde trend betrekking heeft op de kortere periode 1987-1990, terwijl de trendmatige ontwikkeling van de andere historische data en risico-indicatoren is bepaald op basis van de ontwikkeling in de jaren 1979 tot en met 1985 . De afwijkende classificatie voor de trendmatige werkloosheidsontwikkeling (TW) kan op basis van de symmetrische methode worden vastgesteld. Aangezien er bij een waarde van 1 sprake is van een stabiele situatie wordt de trend genormeerd om de waarde 1 . In dit geval echter is het gemiddelde groter dan $1(\mu=1,18)$. Om toch een normering om 1 te verkrijgen, worden de oorspronkelijk met het gemiddelde en de standaardafwijking verkregen grenzen gedeeld door het gemiddelde, hetgeen tot gevolg heeft dat de typeringen 'stijgend' en 'sterk stijgend' relatief veel zullen voorkomen. Dit levert de volgende grenzen op:

$\begin{array}{llll} & \text { TW } \leq & 0,60 & \text { sterk dalend } \\ 0,60 & <\text { TW } \leq & 0,85 & \text { dalend } \\ 0,85 & <\text { TW } \leq & 1,15 & \text { constant } \\ 1,15<\text { stijgend } \\ 1,40< & <W & 1,40 & \text { sterk stijgend }\end{array}$

3. De gehanteerde indeling is vrijwel identiek aan de indeling van vorig jaar (zie De Grip, Heijke, Dekker, Beekman en Peeters, 1989). De enige verandering die is doorgevoerd, is het symmetrisch maken van de indeling. 
Verdeling van de typeringen

Tabel 3 geeft een beeld van de verdeling van de in deze paragraaf gepresenteerde trends over de beroepsklassen of opleidingstypen.

Tabel 3. Verdeling van de typeringen van de bepaalde trends over de beroepsklassen, beroepsgroepen en opleidingstypen"

\begin{tabular}{|c|c|c|c|c|c|c|c|}
\hline typering & TW & TOW & TBW & TL30 & TL49 & TL59 & TL64 \\
\hline sterk dalend & 0 & 1 & 0 & 8 & 0 & 7 & 2 \\
\hline dalend & 7 & 6 & 33 & & 10 & 33 & 53 \\
\hline constant & 26 & 6 & 25 & 22 & 35 & 28 & 14 \\
\hline stijgend & 8 & 40 & 21 & 16 & 32 & 9 & 8 \\
\hline sterk stijgend & 13 & 1 & 1 & 8 & 3 & 3 & 3 \\
\hline totaal & 54 & 54 & 80 & 80 & 80 & 80 & 80 \\
\hline typering & TWO & THB & TMB & TLB & THV & TMV & TBO \\
\hline sterk dalend & 2 & 3 & 1 & 8 & 3 & 5 & 44 \\
\hline dalend & 11 & 10 & 3 & 26 & 18 & 19 & 30 \\
\hline constant & 52 & 33 & 15 & 16 & 26 & 13 & 6 \\
\hline stijgend & 13 & 25 & 29 & 18 & 29 & 26 & 0 \\
\hline sterk stijgend & 2 & 9 & 32 & 12 & 4 & 17 & 0 \\
\hline totaal & 80 & 80 & 80 & 80 & 80 & 80 & 80 \\
\hline typering & $T Z$ & TBGR & TV & TD & TBS & TOS & TOB \\
\hline sterk dalend & 7 & 58 & 24 & 15 & 19 & 3 & 3 \\
\hline dalend & 22 & 71 & 56 & 59 & 13 & 4 & 1 \\
\hline constant & 36 & 53 & 83 & 65 & 38 & 31 & 34 \\
\hline stijgend & 13 & 58 & 80 & 72 & 4 & 13 & 14 \\
\hline sterk stijgend & 2 & 63 & 60 & 92 & 6 & 3 & 2 \\
\hline totaal & 80 & 303 & 303 & 303 & 80 & 54 & 54 \\
\hline
\end{tabular}

* Voor de betekenis van de gebruikte symbolen zie bijlage $\mathrm{A}$.

In zijn algemeenheid kan worden opgemerkt dat de van te voren bepaalde, niet relatief op de gegevens gemaakte grenzenindeling voor de verschillende trends andere gevolgen heeft met betrekking tot de verdeling van de beroepsklassen, beroepsgroepen of opleidingstypen over de onderscheiden kwalitatieve typeringen. 
Tabel 3 laat zien dat de trendmatige werkloosheidsontwikkeling voor 26 opleidingstypen min of meer constant is. Bovendien is er in 13 gevallen sprake is van een sterke stijging van de werkloosheid. Daarbij moet worden bedacht dat, voor opleidingstypen met een werkloosheidspercentage van $5 \%$ of lager, de trendmatige ontwikkeling niet als sterk stijgend is getypeerd, omdat dit, gezien het lage werkloosheidspercentage, een verkeerd beeld zou schetsen ${ }^{4}$.

Verder blijkt uit tabel 3 dat de trendmatige ontwikkeling van het percentage werkenden per opleidingstype (TOW) voor 40 opleidingstypen stijgend is. De trend van het percentage werkenden per beroepsklasse (TBW) wordt in 33 gevallen als dalend getypeerd. De trend van het percentage zelfstandigen per beroepsklasse (TZ) heeft een meer evenwichtige verdeling over de kwalitatieve typeringen. De trends van de beroepsgroepen laten over het algemeen ook een meer gelijkmatige verdeling over de onderscheiden categorieën zien. Daarbij valt echter op dat voor veel beroepsgroepen de trendmatige ontwikkeling van het percentage vrouwen (TV) en deeltijdwerkers (TD) stijgend of sterk stijgend is.

De trendmatige ontwikkeling van de leeftijd (TL30, TL49, TL59 en TL64) is niet bepaald op basis van de gemiddelde leeftijd per beroepsklasse. Deze trend is vastgesteld aan de hand van het in I-See! grafisch weergegeven percentage werkenden dat tot een bepaalde leeftijdscategorie behoort (zie voor de onderscheiden leeftijdsgroepen bijlage A). Het is opvallend dat voor de vrijwel alle leeftijdscategorieën, met uitzondering van die voor de leeftijdsgroep van 31-49 jarigen, geldt dat veel beroepsklassen worden gekenmerkt door een dalende trend. Met name voor de leeftijdsgroep van 60-64 jarigen is de trend van een groot aantal beroepsklassen als dalend getypeerd. Dit is waarschijnlijk in belangrijke mate het gevolg van de invoering van VUT-regelingen in de waarnemingsperiode 1979-1985.

Ook de trendmatige ontwikkeling van de vooropleiding is niet bepaald op basis van het gemiddeld aantal jaren vooropleiding van de werkenden in een beroepsklasse. Voor de verschillende schoolsoorten, te weten het wetenschappelijk onderwijs, de verschillende niveaus van het beroepsonderwijs en de verschillende niveaus van het algemeen onderwijs, zijn aparte trends bepaald (TWO, THB, TMB, TLB, THV, TMV en TBO). Met name het grote aantal beroepsklassen dat te maken heeft met een (sterke) daling van het aantal werkenden met alleen een basisopleiding valt op. Daarnaast blijkt dat voor 52 beroepsklassen geldt dat het aantal werkenden met een universitaire opleiding nagenoeg constant blijft. Het gaat hier overigens in bijna alle gevallen om beroepsklassen waarin vrijwel geen academici werken.

4. De typering 'sterk dalend komt bij de trendmatige ontwikkeling van het werkloosheidspercentage overigens niet voor. 
Wat betreft de trendmatige ontwikkeling van de spreidingscoëfficiënten kan het volgende worden opgemerkt. Voor de branche- en de beroepenspreiding van de opleidingstypen geldt dat ruim 30 van de 54 opleidingstypen een constante spreiding hebben. Bij bijna een derde van de onderscheiden opleidingstypen is sprake van een (sterke) stijging van de uitwijkmogelijkheden op de arbeidsmarkt. De branchespreiding per beroepsklasse laat daarentegen zien dat maar liefst 32 van de 80 beroepsklassen een (sterk) dalende sectorspreiding vertonen. 


\section{ARBEIDSMARKTPROGNOSES}

\subsection{Prognoses beroepsklassen en opleidingstypen}

In deze paragraaf worden de kwalitatieve typeringen met betrekking tot de arbeidsmarktprognoses gepresenteerd. De classificaties van de middellange-termijn voorspelling betreffende de uitbreidingsvraag, de vervangingsvraag en de totale vraag per beroepsklasse en per opleidingstype komen aan de orde. Daarnaast wordt de typering van de verwachte instroom van schoolverlaters op de arbeidsmarkt besproken. De verwachte toekomstige groei van de werkgelegenheid wordt in I-See! aangeduid met de term 'uitbreidingsvraag' (zie De Grip, Heijke en Dekker, 1989). De vervangingsvraag treedt op als gevolg van enerzijds de definitieve uittreding uit de beroepsbevolking (wegens pensionering, VUT, e.d.) en anderzijds de (al dan niet tijdelijke) uittreding van met name gehuwde vrouwen. De vervangingsvraag per beroepsklasse kan bovendien het gevolg zijn van de beroeps(klasse)mobiliteit. De beroepsmobiliteit heeft geen invloed op de vervangingsvraag per opleidingstype (zie Willems en De Grip, 1990). Samen met de uitbreidingsvraag per beroepsklasse geeft de vervangingsvraag per beroepsklasse het verwachte aantal 'job-openings' in de prognoseperiode ofwel de totale vraag per beroepsklasse aan. De totale vraag per opleidingstype, die wordt bepaald aan de hand van de uitbreidings- en vervangingsvraag per opleidingstype, geeft de totale vraag naar nieuwkomers op de arbeidsmarkt weer ${ }^{5}$.

De vaststelling van de kwalitatieve typeringen van de verwachte uitbreidingsvraag (UVB), de vervangingsvraag (VVB) en de totale vraag (TVB) per beroepsklasse heeft plaatsgevonden op basis van de symmetrische methode ${ }^{6}$. De indelingen van de arbeidsmarktprognoses per beroepsklasse luiden als volgt:

5. De totale vraag per beroepsklasse wordt bepaald door de optelsom van de niet negatieve uitbreidingsvraag per beroepsklasse en de vervangingsvraag per beroepsklasse, ofwel:

$T V B=\max \{0, U V B\}+V V B$

Zo wordt ook de totale vraag per opleidingstype bepaald door de optelsom van de niet negatieve uitbreidingsvraag per opleidingstype en de vervangingsvraag per opleidingstype. Dit wordt: $T V O=\max \{0, U V O\}+V V O$ Zie ook Dekker, De Grip, Beekman, Van de Loo, Wieling en Willems (1990).

6. In I-See! 1990 is met betrekking tot de totale vraag per beroepsklasse een indeling gehanteerd die enigszins afwijkt van de in dit werkdocument gepresenteerde typering. 


$\begin{array}{rlr}-10 \% & \text { UVB } \leq & -10 \% \\ 0 \% & <\text { UVB } \leq & 0 \% \\ 9 \% & <\text { UVB } \leq & 9 \% \\ 16 \% & <\text { UVB } \leq & 16 \%\end{array}$

relatief erg laag

relatief laag

gemiddeld

relatief hoog

relatief erg hoog

$\begin{array}{rlr} & \text { VVB } \leq & 5 \% \\ 5 \% & <\text { VVB } \leq & 9 \% \\ 9 \% & <\text { VVB } \leq & 15 \% \\ 15 \% & <\text { VVB } \leq & 19 \% \\ 19 \% & <\text { VVB }\end{array}$

relatief erg laag

relatief laag

gemiddeld

relatief hoog

relatief erg hoog

$\begin{array}{rlr} & & \text { TVB } \leq \\ 5 \% & <\text { TVB } \leq & 5 \% \\ 12 \% & <\text { TVB } \leq & 21 \% \\ 21 \% & <\text { TVB } \leq & 28 \% \\ 28 \% & <\text { TVB }\end{array}$

relatief erg laag

relatief laag

gemiddeld

relatief hoog

relatief erg hoog

In het geval van de verwachte uitbreidingsvraag (UVO), de vervangingsvraag (VVO) en de totale vraag (TVO) per opleidingstype is ook met behulp van de symmetrische methode de grenzenindeling bepaald'. De diverse grenzenindelingen voor de arbeidsmarktprognoses per opleidingstype zien er als volgt uit:

\begin{tabular}{|c|c|c|}
\hline & & UVO $\leq$ \\
\hline$-8 \%$ & $<$ & UVO $\leq$ \\
\hline $3 \%$ & $<$ & UVO $\leq$ \\
\hline $9 \%$ & $<$ & $\begin{array}{l}\text { UVO } \\
\text { UVO }\end{array}$ \\
\hline
\end{tabular}

relatief erg laag

relatief laag

gemiddeld

relatief hoog

relatief erg hoog

\begin{tabular}{|c|c|c|}
\hline & & VVO $\leq$ \\
\hline $4 \%$ & $<$ & VVO $\leq$ \\
\hline $6 \%$ & $<$ & VVO $\leq$ \\
\hline $10 \%$ & $<$ & VVO $\leq$ \\
\hline & $<$ & VVO \\
\hline
\end{tabular}

relatief erg laag

relatief laag

gemiddeld

relatief hoog

relatief erg hoog

\begin{tabular}{|c|c|c|}
\hline $4 \%$ & $<$ & $\begin{array}{l}\text { TVO } \\
\text { TVO }\end{array}$ \\
\hline $11 \%$ & $<$ & TVO $\leq$ \\
\hline $19 \%$ & $<$ & TVO $\leq$ \\
\hline $26 \%$ & $<$ & TVO \\
\hline
\end{tabular}

relatief erg laag

relatief laag

gemiddeld

relatief hoog

relatief erg hoog

7. Ook hier is in I-See! 1990 een indeling gehanteerd die afwijkt van de hier gepresenteerde typering. 
Wat betreft de grenzenindeling van het verwachte toekomstig aanbod van schoolverlaters op de arbeidsmarkt (INS) vanuit de verschillende opleidingstypen kan worden opgemerkt dat het typeren van deze variabele op basis van de symmetrische methode niet zinvol is, daar de spreiding van de verwachte toekomstige instroom van schoolverlaters vrij groot is. In dit geval kan de grenzenindeling echter wel worden bepaald door middel van de kwantielenmethode, hetgeen leidt tot de volgende indeling ${ }^{8}$ :

$\begin{array}{rlrl} & \text { INS } \leq & 7 \% & \text { relatief erg laag } \\ 7 \% & <\text { INS } \leq & 14 \% & \text { relatief laag } \\ 14 \% & <\text { INS } \leq & 40 \% & \text { gemiddeld } \\ 40 \% & <\text { INS } \leq \quad 75 \% & \begin{array}{l}\text { relatief hoog } \\ \text { relatief erg hoog }\end{array} \\ 75 \% & <\text { INS } & & \end{array}$

Verdeling van de typeringen

De verdeling van de typeringen met betrekking tot de verwachte uitbreidingsvraag, de vervangingsvraag, de totale vraag, en de voorspelde instroom van schoolverlaters over de beroepsklassen en/of opleidingstypen staat in tabel 4.

Tabel 4. Verdeling van de typeringen van de prognoses over beroepsklassen en opleidingstypen

\begin{tabular}{lrrrrrrr}
\hline typering & UVB & VVB & TVB & UVO & VVO & TVO & INS \\
\hline relatief erg laag & 3 & 8 & 5 & 4 & 11 & 3 & 5 \\
relatief laag & 21 & 19 & 19 & 12 & 14 & 17 & 11 \\
gemiddeld & 46 & 36 & 41 & 23 & 20 & 24 & 22 \\
relatief hoog & 5 & 11 & 8 & 10 & 5 & 5 & 11 \\
relatief erg hoog & 5 & 6 & 7 & 5 & 4 & 5 & 5 \\
totaal & 80 & 80 & 80 & 54 & 54 & 54 & 54 \\
\hline
\end{tabular}

De classificatie 'gemiddeld' komt bij de arbeidsmarktprognoses per beroepsklasse relatief vaak voor. Opvallend is dat ook de typering 'relatief laag' vaak is toegekend. Met name bij de indeling van de uitbreidingsvraag per beroepsklasse (UVB) is de verdeling van de kwalitatieve typeringen enigszins scheef. Wat betreft de prognoses per opleidingstype kunnen dezelfde opmerkingen worden gemaakt. Tenslotte is in de kolom van de verwachte toekomstige instroom van schoolverlaters (INS) duidelijk de kwantielenmethode te herkennen.

8. Overigens moet worden opgemerkt dat de in dit werkdocument gepresenteerde grenzenindeling met betrekking tot de verwachte toekomstige instroom afwijkt van de in ISee! gehanteerde indeling. 


\subsection{Indicator van de toekomstige arbeidsmarktsituatie}

De verwachte toekomstige arbeidsmarktsituatie voor de diverse opleidingstypen wordt getypeerd met behulp van een indicator, waarin de verwachte vraag en het verwachte aanbod op desbetreffende arbeidsmarktsegment met elkaar worden vergeleken.

In de I-See! versie van 1989 werd de indicator toekomstige arbeidsmarktsituatie (ITA) berekend als (zie Dekker, De Grip en Heijke, 1989):

$$
I T A=\frac{I N S}{U V O+V V O}
$$

Het voordeel van deze specificatie van de arbeidsmarktindicator is zijn eenvoudige interpretatie. Indien de indicator de waarde 1 heeft, zijn vraag en aanbod op het desbetreffende segment van de arbeidsmarkt in evenwicht. Bij de waarde 2 is het aanbod twee keer zo groot als de vraag. Aan deze specificatie van de indicator kleven echter een drietal bezwaren, namelijk:

- de indicator 'explodeert' bij een erg kleine vraag;

- het aanbod van werklozen is niet in de indicator opgenomen;

- de indicator wordt negatief als TVO = UVO + VVO $<0$.

Ter voorkoming van deze bezwaren is de indicator als volgt aangepast ${ }^{8}$ :

$$
I T A=\frac{\frac{E_{89}+I N S+W}{E_{89}}}{\frac{E_{89}+T V O}{E_{29}}} * \frac{100 \%}{100 \%}
$$

waarbij:

$$
\begin{array}{ll}
E_{89} & =\text { werkgelegenheid per opleidingstype voor } 1989 \\
W & =\text { werkloosheid in } 1989 \text { als percentage van } E_{89}
\end{array}
$$

Vergelijking (4) kan worden herschreven als:

$$
I T A=\frac{100+I N S+W}{100+T V O}
$$

9. Zie noot 5. 
Het opnemen van de werkloosheid aan het begin van de prognoseperiode zorgt ervoor dat de waarde van de indicator een beter beeld geeft van de algehele onevenwichtigheid op de arbeidsmarkt voor desbetreffende opleidingscategorie. Bij het bepalen van de indicator zijn alleen de werklozen die korter dan 1 jaar werkloos zijn meegenomen, onder de veronderstelling dat personen die langer dan 1 jaar werkloos zijn niet meer als direct concurrerend aanbod voor de schoolverlaters met de desbetreffende opleidingsachtergrond kunnen worden beschouwd.

Ook bij de nieuwe specificatie van de indicator geldt dat vraag en aanbod in evenwicht als zijn de indicator gelijk is aan 1 . Bij een waarde kleiner of gelijk aan 1 is er sprake is van een 'goed arbeidsmarktperspectief' voor de betreffende opleiding. De overige grenzen zijn echter minder normatief; zij kunnen derhalve op statistische gronden worden bepaald. Net als bij de andere variabelen is ook hier de grenzenindeling afhankelijk van de feitelijke verdeling van de waarde van de indicator per opleidingstype. Aangezien de scholieren/studenten op een gegeven moment een keuze moeten maken voor een bepaalde opleiding, kan vanuit arbeidsmarktoogpunt worden beargumenteerd dat beter voor een opleiding kan worden gekozen die qua typering tot de 'betere' helft behoort, in plaats van een opleidingstype dat behoort tot de 'mindere' helft. Bij een dergelijk uitgangspunt ligt een classificering die gebruikt maakt van de mediaan (Me) voor de hand. Door vervolgens een symmetrische grens rondom de mediaan te leggen, resulteert de volgende indeling:

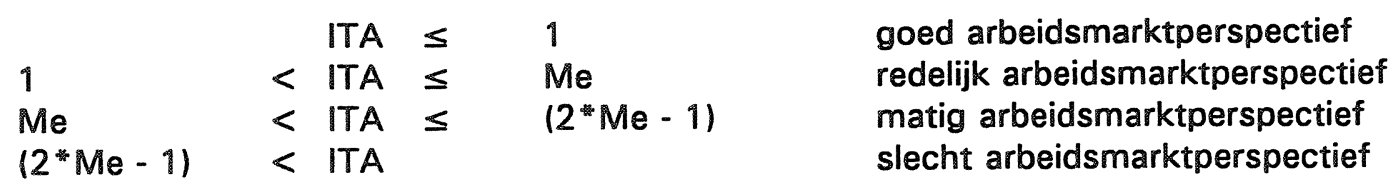

Zoals reeds is aangegeven geldt dat het toekomstige aanbod gelijk is aan de toekomstige vraag naar nieuwkomers als de indicator gelijk is aan 1. Rekening houdend met frictiewerkloosheid en mogelijke bandbreedten bij de voorspellingen ligt het echter voor de hand om deze grens niet precies op 1 te leggen. Gekozen is om het arbeidsmarktperspectief als goed te beoordelen, indien de arbeidsmarktindicator kleiner is dan 1,05. De mediaan van de indicator ligt op 1,15. Echter, omdat bij deze grenzen het aantal opleidingstypen met een matig arbeidsmarktperspectief erg klein wordt en er relatief veel opleidingstypen met een slecht arbeidsmarktperspectief voorkomen, zijn de grenzen als volgt bijgesteld:

$\begin{array}{llll} & \text { ITA } \leq & 1,05 & \text { goed arbeidsmarktperspectief } \\ 1,05 & \text { ITA } \leq & 1,15 & \text { redelijk arbeidsmarktperspectief } \\ 1,15<\text { ITA } \leq & 1,35 & \text { matig arbeidsmarktperspectief } \\ 1,35<\text { ITA } & & & \text { slecht arbeidsmarktperspectief }\end{array}$


Verdeling van de typeringen

Tabel 5 geeft een beeld van de verdeling van de in deze paragraaf gepresenteerde indicator van de toekomstige arbeidsmarktsituatie.

Tabel 5. Verdeling van de typeringen van de indicator van de toekomstige arbeidsmarktsituatie over de opleidingstypen

typering

ITA

goed arbeidsmarktperspectief 15

redelijk arbeidsmarktperspectief

matig arbeidsmarktperspectief

14

slecht arbeidsmarktperspectief

10

15

totaal

54

Uit tabel 5 blijkt dat de opleidingstypen vrijwel gelijk over de typeringen zijn verdeeld. Het blijkt duidelijk uit de tabel dat in dit geval is uitgegaan van de mediaan om een onderscheid te maken tussen enerzijds een goed en redelijk arbeidsmarktperspectief en anderzijds een matig en slecht arbeidsmarktperspectief (ongeveer $50 \%$ behoort tot de eerste groep en ook $50 \%$ behoort tot de 'mindere' helft). Bovendien valt op dat zowel 15 opleidingstypen volgens deze indeling een goed arbeidsmarktperspectief als een slecht arbeidsmarktperspectief hebben. 


\section{BESLUIT}

Door aan de kwantitatieve arbeidsmarktinformatie in het ROA informatiesysteem kwalitatieve typeringen toe te kennen, wordt de interpretatie van de gepresenteerde gegevens eenvoudiger. In deze studie is getracht te komen tot een systematische methode om de kwantitatieve arbeidsmarktinformatie naar kwalitatieve typeringen te vertalen. Dit heeft geresulteerd in een drietal verschillende methoden, die afhankelijk van de aard van de te presenteren informatie zijn toegepast. Deze drie methoden zijn:

- de symmetrische methode

- de kwantielenmethode

- de ad hoc methode

Over de toepassing van de methoden kan het volgende worden opgemerkt. De symmetrische methode is 13 maal gehanteerd. Met name de voor het informatiesysteem belangrijke grenzenindelingen van de arbeidsmarktprognoses, met uitzondering van de verwachte toekomstige instroom van schoolverlaters op de arbeidsmarkt, zijn allen vastgesteld op basis van de symmetrische methode. Hetzelfde geldt voor de kwalitatieve typeringen van de risicoindicatoren. Verder zijn aan de gemiddelde leeftijd, het gemiddeld aantal jaren vooropleiding en de trendmatige werkloosheidsontwikkeling symmetrische grenzen toegewezen.

Voor een aantal variabelen waarvan de spreiding erg groot is, is de kwantielenmethode gehanteerd. Dit is het geval voor het percentage werkenden per beroepsklasse en per opleidingstype, het aantal werkenden per beroepsgroep en het verwachte toekomstige aanbod van schoolverlaters op de arbeidsmarkt. Bovendien is voor een viertal variabelen een ad hoc benadering toegepast, omdat de verdeling deze variabelen extreem scheef is. Het gaat hierbij om: het werkloosheidspercentage, het percentage zelfstandigen per beroepsklasse, het percentage vrouwen per beroepsgroep en het percentage deeltijdwerkers per beroepsgroep.

Met betrekking tot de trends van de verschillende variabelen is voor een ad hoc benadering gekozen. De reden hiervoor is dat voor vrijwel alle trends, met uitzondering van de trendmatige werkloosheidsontwikkeling, én kwalitatieve typering is vastgesteld, die genormeerd is om de waarde 1 als typering van een stabiele ontwikkeling. Op deze wijze kan er een absolute uitspraak worden gedaan over de betreffende trend en indien dit relevant is kunnen de trends onderling worden vergeleken. Tenslotte is de grenzenindeling van de indicator van de verwachte toekomstige arbeidsmarktsituatie vastgesteld met behulp van de mediaan. 
$-25-$

Hoewel met deze studie in onze ogen een belangrijke aanzet is gegeven tot een meer systematische onderbouwing van veel van de arbeidsmarktinformatie uit het ROAinformatiesysteem, blijft het verder ontwikkelen en verbeteren van de in dit werkdocument gepresenteerde methoden voor het indelen van de kwantitatieve arbeidsmarktinformatie wenselijk. Met name in het geval er sprake is van een scheve verdeling moet worden gezocht naar andere criteria om de desbetreffende variabele te typeren. 


\section{LITERATUUR}

Dekker, R.J.P., A. de Grip, Th.B.J. Beekman, P.J.E. van de Loo, M.H. Wieling, E.J.T.A. Willems (1990), Rapportage I-See! 1990, ROA-R-1990/6, Maastricht.

Grip, A. de (1987), Winnaars en verliezers op de arbeidsmarkt 1981-1985: verschuivingen in beroepen- en opleidingsstructuur, in: Tijdschrift voor Arbeidsvraagstukken, jaargang 3, nr. 1987/4, blz. 61-69.

Grip, A. de, J.A.M. Heijke (1988), Arbeidsmarktindicatoren: een inventarisatie, ROA-W-1988/1, Maastricht.

Grip, A. de, J.A.M. Heijke, R.J.P. Dekker, Th.B.J. Beekman, H.M.M. Peeters (1989), De arbeidsmarktperspectieven van beroepsklassen en opleidingstypen in 1992: rapportage ISee!, ROA-R-1989/7, Maastricht.

Grip, A. de, J.A.M. Heijke, R.J.P. Dekker (1989), De arbeidsmarkt naar opleiding en beroep in 1992, ROA-R-1989/8, Maastricht.

Sheldon, G. (1985), Die berufliche und geographische Flexibilität, Institut für Arbeidsmarkt und Berufsforschung der Bundesanstalt für Arbeit, Beitrage AB 92, Nürnberg.

Warnken, J. (1986), Zur Entwicklung der "internen" Anpassungsfähigkeit der Berufe bis zum Jahre 2000. Projektionen unter den Annahmen der Wachstumsszenarien der Prognos-Studie, in: Mitteilungen aus der Arbeidsmarkt- und Berufsforschung, no.1, blz. 119-133.

Willems, E.J.T.A., A. de Grip (1990), Vervangingsvraagprognoses naar beroep en opleiding, ROA-W-1990/7, Maastricht. 


\section{BIJLAGE A: LIJST MET AFKORTINGEN}

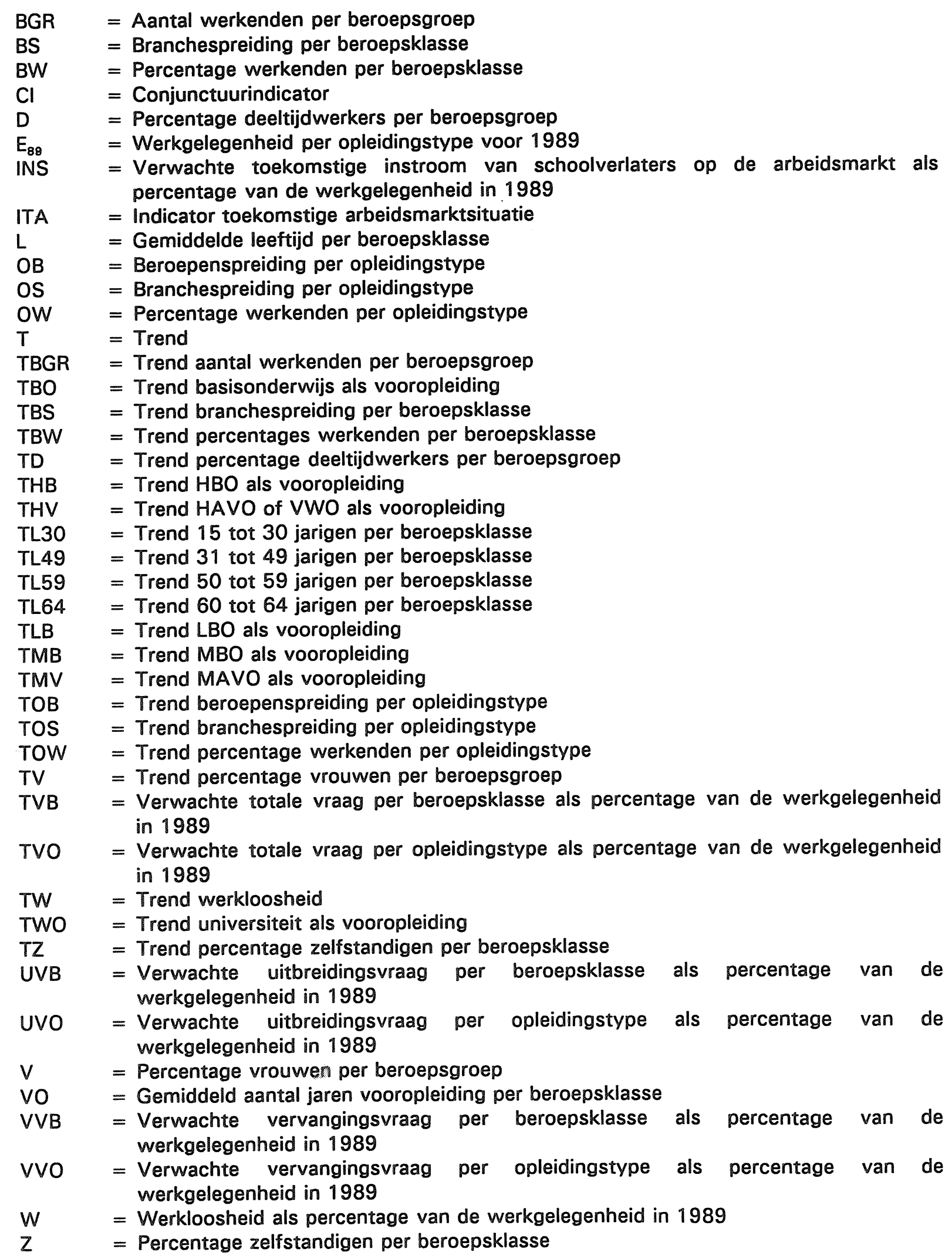


$-28-$

BIJLAGE B: GEMIDDELDEN EN STANDAARDDEVIATIES VAN DE VARIABELEN

\begin{tabular}{lrr} 
variabele & gemiddelde & standaarddeviatie \\
\hline & & \\
W & & \\
OW & 7,57 & 7,00 \\
BW & 1,69 & 3,24 \\
L & 1,23 & 1,54 \\
VO & 37,08 & 3,13 \\
Z & 10,32 & 2,29 \\
BGR & 11,48 & 23,10 \\
V & 15.882 & 30.017 \\
D & 18,68 & 25,20 \\
CI & 10,82 & 14,72 \\
BS & 1,75 & 0,60 \\
OS & 0,52 & 0,30 \\
OB & 0,70 & 0,22 \\
TW & 0,73 & 0,20 \\
UVB & 1,18 & 0,36 \\
VVB & 3,05 & 10,26 \\
TVB & 11,95 & 5,39 \\
UVO & 16,80 & 9,01 \\
VVO & 6,05 & 10,64 \\
TVO & 7,34 & 3,38 \\
INS & 15,02 & 8,50 \\
ITA & 35,39 & 31,43 \\
& 1,25 & 0,30 \\
\hline
\end{tabular}

